\title{
NEUROPATI PERIFER PADA PENYANDANG TALASEMIA DI POLIKLINIK HEMATO-ONKOLOGI RSUP DR. HASAN SADIKIN BANDUNG
}

\author{
PERIPHERAL NEUROPATHY IN THALASSEMIA PATIENTS AT \\ HAEMATO-ONCOLOGY CLINIC HASAN SADIKIN GENERAL \\ HOSPITAL BANDUNG \\ Uni Gamayani, * Fanny Adhy Putri, * Nushrotul Lailiyya, * Pandji Irani Fianza, ** Ramdan Panigoro***
}

\begin{abstract}
Introduction: Thalassemia is an inherited blood disorder with high prevalence that can lead to various neurological complications such as peripheral neuropathy. Peripheral neuropathy in thalassemia patients is commonly subclinical. Chronic hypoxia due to anemia and iron deposition are thought to be the risk factors for neuropathy in thalassemia. Nerve Conduction Study (NCS) is the gold standard in diagnosing peripheral neuropathy.

Aims: To identify peripheral neuropathy among thalassemia patients in Hemato-oncology Clinic at Hasan Sadikin General Hospital, Bandung.

Method: This was a cross sectional, observational descriptive study conducted on thalassemia patients who regularly underwent blood transfusion in Haemato-oncology Clinic at Hasan Sadikin General Hospital, Bandung. The study was held from November 2017 until March 2018. All subjects who met inclusion criteria and did not meet any exclusion criteria were assessed with neurological examination, Toronto clinical score and NCS.

Results: Forty subjects with mean age $21.8 \pm 6.4$ years old, $57.5 \%$ were female. The mean hemoglobin level was $7.3 \pm 0.7 \mathrm{~g} / \mathrm{dL}$ and mean ferritin serum level was $5,032 \pm 3,423 \mu \mathrm{g} / \mathrm{L}$. The median Toronto clinical score was 4 (0-7) with normal, mild neuropathy, and moderate neuropathy in $55 \%, 42.5 \%$, and $2.5 \%$ subjects respectively. Ninety percent patients had abnormal NCS examination with axonal degeneration found in $57.5 \%$ subjects and polyneuropathy in $82.5 \%$ subjects.
\end{abstract}

Discussion: Peripheral neuropathy were found in most adult thalassemia patients. Although, NCS examination is important to established definitive diagnosis and considered to be performed in thalassemia patients to diagnose peripheral neuropathy.

Keywords: NCS, peripheral neuropathy, thalassemia, Toronto clinical score

\section{ABSTRAK}

Pendahuluan: Talasemia adalah penyakit kelainan darah herediter dengan prevalensi tinggi dan menimbulkan komplikasi neurologis berupa neuropati perifer. Neuropati perifer pada penyandang talasemia seringkali bersifat subklinis. Hipoksia jaringan akibat anemia kronis dan deposisi besi karena transfusi dicurigai sebagai faktor risiko terjadinya neuropati perifer pada talasemia. Standar baku diagnosis neuropati perifer adalah dengan pemeriksaan Kecepatan Hantar Saraf (KHS).

Tujuan: Untuk mengetahui adanya neuropati perifer pada penyandang talasemia di Poliklinik Hemato-Onkologi Medik RSUP Dr. Hasan Sadikin, Bandung.

Metode: Penelitian ini bersifat deskriptif observasional, dengan rancangan potong lintang, dilakukan pada subjek penyandang talasemia yang rutin menjalani transfusi di Poliklinik Hemato-Onkologi Medik RSUP Dr. Hasan Sadikin, Bandung. Penelitian dilakukan sejak November 2017 sampai Maret 2018. Seluruh subjek yang memenuhi kriteria inklusi dan tidak memiliki kriteria eksklusi dilakukan pemeriksaan neurologis, skor klinis Toronto dan KHS.

Hasil: Sebanyak 40 subjek berusia rerata 21,8 $\pm 6,4$ tahun, 57,5\% perempuan. Rerata kadar hemoglobin 7,3 $\pm 0,7 \mathrm{~g} /$ $\mathrm{dL}$ dan rerata kadar feritin 5,032 $\pm 3,423 \mu \mathrm{g} / \mathrm{L}$. Skor klinis neuropati Toronto didapatkan median $4(0-7)$ dengan interpretasi tidak ada neuropati, neuropati ringan dan neuropati sedang berturut-turut pada 55\%, 42,5\%, dan 2,5\% subjek. Sebanyak $90 \%$ subjek memiliki gambaran KHS abnormal, polineuropati didapatkan pada $82,5 \%$ subjek dan gambaran degenerasi aksonal pada $57,5 \%$ subjek.

Diskusi: Neuropati perifer terjadi pada sebagian besar penyandang talasemia dewasa. Pemeriksaan KHS diperlukan untuk diagnosis pasti dan dipertimbangkan untuk dilakukan pada penyandang talasemia.

Kata kunci: KHS, neuropati perifer, skor klinis Toronto, talasemia

*Departemen Neurologi FK Universitas Padjadjaran/RSUP Dr. Hasan Sadikin, Bandung; **Departemen Ilmu Penyakit Dalam FK Universitas Padjadjaran/RSUP Dr. Hasan Sadikin, Bandung; ***Pusat Studi Genetika FK Universitas Padjadjaran, Bandung. Korespondensi: gamayani@yahoo.com. 


\section{PENDAHULUAN}

Neuropati perifer merupakan salah satu komplikasi neurologis sistem saraf perifer yang banyak terjadi pada berbagai penyakit, salah satunya pada talasemia. Terapi yang diberikan sampai saat ini adalah transfusi darah teratur dan kelasi besi yang membuat usia harapan hidup meningkat. Namun demikian, komplikasi talasemia maupun terapi yang diberikan dapat menimbulkan komplikasi pada saraf tepi berupa neuropati perifer. Hipoksia jaringan yang terjadi akibat anemia kronis dan deposisi besi yang berasal dari transfusi dicurigai sebagai penyebab neuropati pada penyandang talasemia. ${ }^{1-4}$

Prevalensi neuropati perifer relatif cukup tinggi pada penyandang talasemia. Penelitian Stamboulis dkk pada 36 penyandang talasemia beta mayor, didapatkan 52,7\% neuropati perifer dengan hasil konduksi saraf berupa polineuropati sensorik dengan gambaran degenerasi aksonal. ${ }^{5}$ Penelitian Krisanti di Poliklinik Talasemia RSUP Dr. Hasan Sadikin (RSHS) Bandung pada penyandang talasemia beta mayor usia 8-14 tahun didapatkan 98\% neuropati perifer dengan gambaran NCS abnormal berupa kelainan campuran aksonal dan demielinisasi baik pada saraf sensorik maupun motorik pada $46,94 \%$

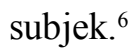

Keluhan neuropati pada penyandang talasemia seringkali terabaikan dan dapat menurunkan kualitas hidup penyandang, namun sebagian besar keluhan bersifat subklinis dan baru terdiagnosis dengan pemeriksaan neurologis dan pemeriksaan penunjang lebih lanjut, salah satunya adalah pemeriksaan konduksi saraf. ${ }^{7-9}$ Gambaran konduksi saraf yang abnormal juga dapat ditemukan pada penyandang yang belum menunjukkan gejala dan atau tanda neuropati. Di RSHS sendiri, belum terdapat data mengenai angka kejadian neuropati perifer sebagai komplikasi dari talasemia. Penelitian ini diharapkan dapat digunakan untuk deteksi dini gangguan saraf perifer dan meningkatkan kualitas hidup penyandang talasemia.

\section{TUJUAN}

Tujuan penelitian ini untuk mengetahui adanya neuropati perifer pada penyandang talasemia di Poliklinik Hemato-Onkologi Medik RSHS, Bandung.

\section{METODE}

Subjek pada penelitian ini adalah seluruh pasien yang telah didiagnosis talasemia dan rutin menjalani transfusi ke Poliklinik Hemato-Onkologi Medik RSHS, Bandung, yang memenuhi kriteria inklusi usia $>14$ tahun dan bersedia mengikuti penelitian dan tidak termasuk kriteria eksklusi, yaitu sedang atau pernah menggunakan obat-obatan yang dapat menyebabkan neuropati perifer seperti obat kemoterapi (vinkristin) atau obat tuberkulosis (isoniazid), adanya gangguan ginjal, gangguan fungsi hepar maupun diabetes melitus.

Penelitian ini bersifat deskriptif dengan teknik pengambilan data melalui kuesioner, pemeriksaan fisik neurologis, skor klinis Toronto dan pemeriksaan konduksi saraf dengan desain penelitian potong lintang. Pengambilan sampel secara non-probability sampling dengan metode consecutive sampling. Data hasil penelitian dideskripsikan menggunakan tabel sesuai dengan variabel yang diidentifikasi selama penelitian.

Pemeriksaan Kecepatan Hantar Saraf (KHS) dilakukan pada saraf sensorik N. Medianus, N. Ulnaris, N. Suralis bilateral, dan saraf motorik dilakukan pemeriksaan pada N. Medianus, N. Ulnaris, N. Peroneus, dan N. Tibialis bilateral. Parameter yang diukur pada KHS adalah konduksi hantar saraf, amplitudo, dan latensi distal Compound Muscle Action Potential (CMAP) saraf yang diperiksa. Interpretasi pemeriksaan KHS dikategorikan sebagai normal, mononeuropati bila didapatkan kelainan yang terlokalisasi pada satu saraf, mononeuropati multipleks bila didapatkan kelainan pada beberapa saraf yang bersifat asimetris dan berasal dari trunkus saraf yang berbeda dan polineuropati bila didapatkan kelainan pada beberapa saraf yang bersifat simetris.

\section{HASIL}

Penelitian ini dilaksanakan pada bulan November 2017 sampai dengan Maret 2018. Subjek adalah penyandang talasemia yang menjalani transfusi rutin di Poliklinik Hemato-Onkologi Medik RSHS, Bandung. Selama kurun waktu tersebut 
diperoleh 40 subjek yang memenuhi kriteria inklusi dan tidak memiliki kriteria eksklusi. Setelah subjek menandatangani formulir informed consent, dilakukan anamnesis dan pemeriksaan neurologis, penilaian skor klinis Toronto kemudian dijadwalkan untuk pemeriksaan KHS. Karakteristik subjek penelitian dapat dilihat pada Tabel 1 .
Tabel 1 menunjukkan bahwa rerata usia $21,8 \pm 6,4$ tahun dan perempuan 57,5\%. Subjek penelitian ini terdiri atas $90 \%$ penyandang talasemia beta mayor dan $10 \%$ penyandang talasemia beta minor. Rerata diagnosis talasemia ditegakkan pada usia 2,9 $\pm 3,9$ tahun dengan rerata lama terdiagnosis adalah $18,9 \pm 5,9$ tahun. Interval waktu antar transfusi

Tabel 1. Karakteristik Subjek Penelitian

\begin{tabular}{|c|c|c|c|c|}
\hline Karakteristik & Rerata \pm SD & Median & Range & n (\%) \\
\hline Usia (tahun) & $21,80 \pm 6,44$ & & $15,00-47,00$ & \\
\hline \multicolumn{5}{|l|}{ Jenis kelamin } \\
\hline - Laki-laki & & & & $17(42,5)$ \\
\hline - Perempuan & & & & $23(57,5)$ \\
\hline \multicolumn{5}{|l|}{ Jenis talasemia } \\
\hline - Mayor & & & & $36(90)$ \\
\hline - Minor & & & & $4(10)$ \\
\hline Usia terdiagnosis (tahun) & $2,89 \pm 3,86$ & & $0,25-18,50$ & \\
\hline Lama terdiagnosis (tahun) & $18,88 \pm 5,88$ & & $9,50-42,00$ & \\
\hline Jarak antar transfusi (minggu) & & 4,00 & $2,00-8,00$ & \\
\hline \multicolumn{5}{|l|}{ Pendidikan } \\
\hline - $\mathrm{SD}$ & & & & $3(7,5)$ \\
\hline - SMP & & & & $16(40)$ \\
\hline - SMU & & & & $18(45)$ \\
\hline - $\mathrm{S} 1$ & & & & $3(7,5)$ \\
\hline Kadar Hb (g/dL) & $7,34 \pm 0,72$ & & $5,90-9,60$ & \\
\hline Kadar hematokrit (\%) & $22,49 \pm 2,89$ & & $17,60-29,10$ & \\
\hline Kadar feritin $(\mu \mathrm{g} / \mathrm{L})$ & $5032,50 \pm 3423,07$ & & $1045,00-15350,00$ & \\
\hline \multicolumn{5}{|l|}{ Penggunaan kelasi besi } \\
\hline - Ya & & & & $39(97,5)$ \\
\hline ○ Deferoksamin (DFO) & & & & $5(12,5)$ \\
\hline$\circ$ Deferipron (DFP) & & & & $15(37,5)$ \\
\hline ○ Deferasiroks (DFX) & & & & $19(47,5)$ \\
\hline \multicolumn{5}{|l|}{ Jenis darah } \\
\hline - $\mathrm{PRC}$ & & & & $14(35)$ \\
\hline - WRC & & & & $1(2,5)$ \\
\hline - PRC OPTI & & & & $25(62,5)$ \\
\hline $\begin{array}{l}\text { Jumlah saraf abnormal pada } \\
\text { pemeriksaan KHS }\end{array}$ & & 4 & $0-7$ & \\
\hline \multicolumn{5}{|c|}{ Jenis neuropati dari pemeriksaan NCS } \\
\hline - Tidak ada neuropati & & & & $4(10)$ \\
\hline - Mononeuropati multipleks & & & & $3(7,5)$ \\
\hline - Polineuropati & & & & $33(82,5)$ \\
\hline
\end{tabular}

Untuk data kategorik disajikan dalam frekuensi dan persentase, sedangkan data numerik disajikan dalam rerata, standar deviasi (SD), median, dan range; KHS: kecepatan hantar saraf; NCS: Nerve Conduction Study; PRC: Packed Redblood Cells, WRC: Washed Redblood Cells. 
adalah setiap 4 minggu. Karakteristik demografi dan klinis subjek penelitian dapat dilihat pada Tabel 1.

Pemeriksaan skor neuropati Toronto didapatkan median 4 (0-8) dengan interpretasi skala Toronto tidak ditemukan neuropati pada 55\% subjek, $42,5 \%$ subjek dengan neuropati ringan dan $2,5 \%$ subjek dengan neuropati sedang.

Pemeriksaan KHS dilakukan pada seluruh subjek penelitian. Tabel 2 menjelaskan gambaran hasil pemeriksaan NCS secara keseluruhan. Berdasarkan jenis neuropati yang ditemukan, $82,5 \%$ didapatkan gambaran polineuropati, 7,5\% mononeuropati multipleks dan $10 \%$ subjek dengan gambaran KHS normal.

Tabel 2. Gambaran Konduksi Saraf Tepi Subjek Penelitian ( $\mathrm{n}=40)$

\begin{tabular}{lc}
\hline \multicolumn{1}{c}{ Karakteristik NCS } & n (\%) \\
\hline KHS normal & $4(10)$ \\
NCS abnormal & $36(90)$ \\
- Degenerasi aksonal & $23(57,5)$ \\
- Demielinisasi & $0(0)$ \\
- Demielinisasi aksonal & $13(32,5)$ \\
Jenis neuropati & \\
- Mononeuropati multipleks & $3(7,5)$ \\
- Polineuropati & $33(82,5)$ \\
\hline
\end{tabular}

Untuk data kategorik disajikan dalam frekuensi dan persentase.

\section{PEMBAHASAN}

Subjek penelitian ini berusia 15-47 tahun, yaitu penyandang talasemia beta mayor dan minor yang rutin menjalani transfusi di Poliklinik Hemato-Onkologi Medik RSHS, Bandung. Peneliti Papanastasiou $^{10}$ mendapatkan rerata usia harapan hidup penyandang talasemia adalah hingga dekade keempat dengan komplikasi neuropati perifer terutama ditemukan pada usia dekade kedua.

Distribusi jenis kelamin wanita pada subjek penelitian ini sebanyak $57,5 \%$, sedikit lebih banyak dibandingkan dengan laki-laki, karena penelitian dilakukan dengan metode potong lintang dengan pemilihan subjek berupa metode consecutive sampling. Penelitian Stamboulis ${ }^{5}$ dan Zafeiriou $^{11}$ dan Sawaya $^{12}$ didapatkan tidak ada perbedaan bermakna dari jenis kelamin subjek. Hal ini sesuai dengan teori bahwa talasemia diturunkan secara autosomal resesif, sehingga tidak ada hubungannya dengan jenis kelamin. ${ }^{13-14}$

Diagnosis talasemia subjek penelitian ini ratarata di bawah 3 tahun dengan lama diagnosis $>10$ tahun. Penyandang talasemia dapat terdiagnosis paling dini pada usia 3 bulan dan paling sering sebelum usia 2 tahun. ${ }^{15}$ Papanastasiou $^{10}$ dalam penelitiannya menyatakan bahwa lama terdiagnosis berhubungan dengan kejadian neuropati. Papanastasiou $^{10}$ menemukan bahwa komplikasi neuropati perifer sering ditemukan pada usia dekade kedua dari penyandang talasemia. Hal ini disebabkan oleh hipoksia yang kronis pada jaringan saraf. Penelitian ini dilakukan pada penyandang dengan rerata terdiagnosis $18,88 \pm 5,88$ tahun sehingga kemungkinan telah terjadi anemia kronis yang menyebabkan hipoksia pada jaringan saraf.

Penelitian Stamboulis ${ }^{5}$ menyatakan bahwa neuropati perifer lebih banyak didapat pada penyandang talasemia dengan rerata kadar hemoglobin kurang dari $10 \mathrm{~g} / \mathrm{dL}$ dan berhubungan dengan status anemia yang kronis, sedangkan Sawaya $^{12}$ mendapatkan rerata kadar hemoglobin pratransfusi pada subjek penelitiannya adalah $9 \mathrm{~g} /$ dL dengan rentang 6,4 sampai $12,7 \mathrm{~g} / \mathrm{dL} .{ }^{12}$ Sama halnya dengan penelitian ini yaitu kadar $\mathrm{Hb}$ rerata kurang dari $10 \mathrm{~g} / \mathrm{dL}$. Kadar hemoglobin yang rendah menyebabkan hipoksia kronis sehingga terjadi gangguan pada vasa nervorum dan mengganggu aliran darah, suplai oksigen dan pompa Na-K ATPase pada akson saraf perifer yang menyebabkan neuropati perifer. ${ }^{16-18}$

Papanastasiou $^{10}$ serta Stamboulis ${ }^{5}$ menyatakan bahwa gambaran KHS yang abnormal pada penyandang talasemia berhubungan dengan berat dan lamanya anemia, namun tidak memiliki hubungan dengan kadar feritin, pemberian kelasi besi, splenektomi maupun lamanya transfusi..$^{5,10}$ Stamboulis $^{5}$ menambahkan dalam penelitiannya didapatkan hasil pemeriksaan elektrofisiologis berupa degenerasi aksonal, yang diakibatkan hipoksia yang kronis. ${ }^{5}$

Penelitian Borgna-Pignatti ${ }^{19}$ di Italia dan pedoman dari Thalassemia International Federation 
(TIF) tahun 2014 yang menyatakan bahwa kadar feritin serum $\geq 1000 \mu \mathrm{g} / \mathrm{L}$ sudah menunjukkan tanda akumulasi besi yang berlebihan di dalam tubuh dan dapat menimbulkan berbagai komplikasi. ${ }^{8,19-20}$ Rerata kadar feritin pada penelitian ini lebih tinggi dibandingkanpenelitian Papanatasiou ${ }^{10}$ dengan rerata kadar feritin $3.714 \pm 2.588 \mu \mathrm{g} / \mathrm{L}$, penelitian $Z_{\text {afeirou }}{ }^{11}$ dengan rerata kadar feritin $2.170 \pm 1.070,9 \mu \mathrm{g} / \mathrm{L}$, maupun penelitian Stamboulis ${ }^{5}$ dengan rerata kadar feritin $2.426,5 \pm 2.355 \mu \mathrm{g} / \mathrm{L} .{ }^{5,10-11} \quad$ Zafeiriou $^{11}$ dan Sawaya $^{12}$ menyatakan bahwa kejadian neuropati perifer mempunyai hubungan bermakna dengan beratnya deposisi besi yang kronis dan diduga juga merupakan faktor risiko utama terjadinya neuropati perifer pada penyandang talasemia. ${ }^{11-12}$ Bayhan menyatakan bahwa didapatkan pemanjangan latensi distal yang bermakna pada penyandang talasemia beta mayor. ${ }^{7}$ Akumulasi besi yang berlebihan pada saraf perifer menghasilkan reactive oxygen species (ROS) dan menyebabkan kerusakan jaringan saraf terutama pada mielin, sehingga didapatkan gambaran demielinisasi pada pemeriksaan KHS. ${ }^{16}$ Subjek penelitian ini memiliki rerata kadar feritin serum yang lebih tinggi dari penelitian-penelitian sebelumnya sehingga kemungkinan telah terjadi deposisi besi yang berlebihan pada berbagai organ, termasuk saraf perifer.

Terapi kelasi besi oral didapatkan pada $85 \%$ subjek, sedangkan 12,5\% subjek mendapatkan terapi kelasi besi parenteral deferoksamin (DFO). Penelitian Papanastasiou, ${ }^{10} \quad$ Stamboulis $^{5}, \quad$ dan Zafeiriou $^{11}$ di Yunani, serta penelitian Sawaya ${ }^{12}$ di Libanon seluruh subjeknya menggunakan DFO sebagai terapi kelasi. Deferoksamin diketahui sebagai jenis kelasi besi dengan efikasi terbaik untuk mengurangi deposisi besi pada saraf perifer, tetapi terapi kelasi oral lebih disukai karena penggunaannya lebih mudah dan nyaman untuk penyandang talasemia dan berkaitan dengan tingkat kepatuhan yang lebih baik. ${ }^{20} \mathrm{Xia}^{21}$ menyatakan bahwa penggunaan DFP sebagai monoterapi sama efektifnya dengan penggunaan DFO dalam mengurangi kadar serum feritin. Subjek penelitian ini hampir seluruhnya menggunakan terapi kelasi, hanya 1 subjek yang tidak mengkonsumsi terapi kelasi yang diberikan, namun didapatkan nilai rerata feritin serum yang tinggi pada seluruh subjek penelitian. Hal ini diperkirakan karena ketidakpatuhan dalam penggunaan terapi kelasi besi, namun hal ini tidak diteliti lebih lanjut dalam penelitian ini.

Skor skala neuropati Toronto pada penelitian ini didapatkan interpretasi abnormal pada $45 \%$ subjek dengan hasil KHS yang abnormal pada $90 \%$ subjek penelitian. Neuropati perifer pada penyandang talasemia seringkali bersifat subklinis dan diabaikan oleh penyandang sehingga baru terdiagnosis dengan pemeriksaan neurologis dan pemeriksaan penunjang lebih lanjut, salah satunya adalah KHS. ${ }^{3}$

Gambaran polineuropati didapatkan sebanyak $82,5 \%$ dan pada $7,5 \%$ penyandang ditemukan gambaran neuropati berupa mononeuropati multipleks. Hasil ini sesuai dengan seluruh penelitian sebelumnya, yaitu gambaran NCS abnormal yang terbanyak adalah polineuropati. ${ }^{6-7,10,12}$ Polineuropati merupakan jenis neuropati perifer yang paling sering terjadi, umumnya disebabkan oleh gangguan sistemik dan metabolik. Namun dapat juga ditemukan jenis neuropati lainnya berupa mononeuropati dan mononeuropati multipleks. Talasemia merupakan kelainan sintesis hemoglobin yang menyebabkan anemia, bersifat sistemik sehingga dapat menyebabkan gangguan pada beberapa saraf secara bersamaan sehingga memberikan gambaran NCS berupa polineuropati. ${ }^{6,21}$

Jenis lesi yang dominan pada penelitian ini adalah degenerasi aksonal yang terlihat dari hasil pemeriksaan NCS berupa gangguan pada amplitudo. Hasil ini sesuai dengan penelitian sebelumnya oleh Papanastasiou, Stamboulis dan Sawaya, didapatkan jenis lesi terbanyak adalah lesi aksonal., ${ }^{5,10}$ Papanastasiou dan Stamboulis juga menyatakan bahwa terdapat hubungan antara rendahnya kadar hemoglobin dengan kejadian neuropati. Rendahnya kadar hemoglobin pada subjek penelitian ini menyebabkan terjadinya hipoksia kronis sehingga terjadi gangguan pada pompa Na-K ATPase, gangguan pada stabilitas membran dan transpor aksonal, yang mengakibatkan atrofi pada akson dan gangguan pada konduksi saraf. ${ }^{13,17}$ 
Pada penelitian ini tidak didapatkan gambaran demielinisasi pada penyandang talasemia, namun ditemukan gambaran degenerasi aksonal dan aksonal demielinisasi. Kadar feritin yang tinggi terutama menyebabkan demielinisasi pada saraf perifer. Smith menyatakan bahwa setelah terjadi demielinisasi, kaliber akson akan berkurang dan terbentuk distribusi abnormal pada neurofilamen yang menyebabkan kerusakan aksonal pada saraf perifer sehingga dapat ditemukan gambaran KHS berupa degenerasi aksonal maupun campuran dari aksonal demielinisasi. Penelitian Smith yang dilakukan pada tikus didapatkan degenerasi aksonal yang terjadi setelah demielinisasi baru didapatkan gejalanya setelah periode 9 bulan. Neuropati perifer yang terjadi pada penyandang talasemia pada awalnya bersifat subklinis dan berlangsung kronis, sehingga pada saat dilakukan pemeriksaan, ditemukan degenerasi aksonal, demielinisasi, maupun campuran dari keduanya, akibat dari adanya anemia kronis dan deposisi besi pada saraf perifer penyandang talasemia. ${ }^{22}$

Penelitian ini mendapatkan kejadian neuropati perifer yang cukup tinggi dan berhubungan dengan anemia kronis serta deposisi besi. Pemeriksaan KHS diharapkan dapat menjadi prosedur rutin yang dilakukan terhadap penyandang talasemia. Transfusi darah yang rutin dengan target hemoglobin $>10 \mathrm{~g} /$ $\mathrm{dL}$ dan pengendalian kadar feritin dengan terapi kelasi besi yang adekuat diharapkan dapat mencegah terjadinya neuropati perifer dan meningkatkan kualitas hidup penyandang talasemia.

Pada penelitian ini adanya defisiensi vitamin dan mikronutrien sebagai penyebab neuropati perifer belum dapat disingkirkan karena tidak dilakukan pemeriksaan kadar vitamin dan pada subjek penelitian.

\section{KESIMPULAN}

Pada sebagian besar penyandang talasemia didapatkan neuropati perifer. Mayoritas gejala neuropati perifer bersifat subklinis sehingga pemeriksaan KHS perlu untuk dilakukan. Pemeriksaan KHS pada subjek penelitian didapatkan gambaran polineuropati, terutama polineuropati tipe aksonal baik pada saraf sensorik dan saraf motorik.

\section{UCAPAN TERIMA KASIH}

Penelitian ini mendapatkan Hibah RFU FK UNPAD periode tahun 2017 di bawah naungan Pusat Studi Genetika FK UNPAD yang telah memberikan fasilitas dan pendanaan sehingga penelitian ini dapat berlangsung dan diselesaikan dengan baik.

\section{DAFTAR PUSTAKA}

1. Tyan PI, Radwan AH, Eid A, Haddad AG, Wehbe D, Taher AT. Novel approach to reactive oxygen species in nontransfusion-dependent thalassemia. BioMed Res Int. 2014;2014:350432.

2. Oliveros O, Trachtenberg F, Haines D, Gerstenberger E, Martin M, Carson S, dkk. Pain over time and its effects on life in thalassemia. Am J Hematol. 2013;88(11):939-43.

3. Hosseini MS, Rostami Z, Saadat A, Saadatmand SM, Naeimi E. Anemia and microvascular complications in patients with type 2 diabetes mellitus. Nephrourol Mon. 2014;6(4):e19976.

4. Nemtsas P, Arnaoutoglou M, Perifanis V, Koutsouraki E, Orologas A. Neurological complications of betathalassemia. Ann Hematol. 2015;94(8):1261-5.

5. Stamboulis E, Vlachou N, Drossou-Servou M, Tsaftaridis P, Koutsis G, Katsaros N, dkk. Axonal sensorimotor neuropathy in patients with $\beta$-thalassaemia. J Neurol Neurosurg Psychiatry. 2004;75(10):1483-6.

6. Krisanti W. Hubungan antara kadar haemoglobin, feritin serum dengan gambaran Nerve Conduction Study (NCS) penyandang talasemia beta mayor usia 8-14 tahun di rumah sakit Hasan Sadikin Bandung. Bandung: Padjadjaran University; 2017. Bayhan T, Unal S, Konuşkan B, Erdem O, Karabulut E, Gumruk F. Assessment of peripheral neuropathy in patients with $\beta$-thalassemia via electrophysiological study: reevaluation in the era of iron chelators. Hemoglobin. 2018;42(2):113-6.

7. Borgna-Pignatti C, Gamberini MR. Complications of thalassemia major and their treatment. Expert Rev Hematol. 2011;4(3):353-66.

8. Musallam KM, Angastiniotis M, Eleftheriou A, Porter JB. Cross-talk between available guidelines for the management of patients with beta-thalassemia major. Acta Haematol. 2013;130(2):64-73.

9. Papanastasiou DA, Papanicolaou D, Magiakou AM, Beratis NG, Tzebelikos E, Papapetropoulos T. Peripheral neuropathy in patients with betathalassaemia. J Neurol Neurosurg Psichiatry. 1991;54(11):997.

10. Zafeiriou DI, Economou M, Athanasiou-Metaxa M. Neurological complications in $\beta$-thalassemia. Brain Dev. 2006;28(8):477-81. 
11. Sawaya RA, Zahed L, Taher A. Peripheral neuropathy in thalassaemia. Ann Saudi Med. 2006;26(5):358-63.

12. Nienhuis AW, Nathan DG. Pathophysiology and clinical manifestations of the $\beta$-thalassemias. Cold Spring Harb Perspect Med. 2012;2(12):a011726.

13. Saliba AN, El Rassi F, Taher AT. Clinical monitoring and management of complications related to chelation therapy in patients with beta-thalassemia. Expert Rev Hematol. 2016;9(2):151-68.

14. Higgs DR, Engel JD, Stamatoyannopoulos G. Thalassaemia. Lancet. 2012;379(9813):373-83.

15. Elsayh KI, Zahran AM, El-Abaseri TB, Mohamed AO, El-Metwally TH. Hypoxia biomarkers, oxidative stress, and circulating microparticles in pediatric patients with thalassemia in Upper Egypt. Clin Appl Thromb Hemos. 2014;20(5):536-45.

16. Vichinsky E, Neumayr L, Trimble S, Giardina PJ, Cohen AR, Coates T, dkk. Transfusion complications in thalassemia patients: a report from the centers for disease control and prevention (CME). Transfusion. 2014;54(4):972-81.
17. Chung T, Prasad K, Lloyd TE. Peripheral neuropathy: clinical and electrophysiological considerations. Neuroimaging Clin N Am. 2014;24(1):49-65.

18. Borgna-Pignatti C, Galanello R. Thalassemias and related disorders: quantitative disorders of hemoglobin synthesis. Wintrobe's clinical hematology. Philadelphia: Wilkins; 2004.

19. Cappellini M, Cohen A, Porter J, Taher A, Viprakasit V, editor. Guidelines for the management of transfusion depedent thalassaemia (TDT). Edisi ke-3. Nicosia: Thalassemia International Federation; 2014.

20. Xia S, Zhang W, Huang L, Jiang H. Comparative efficacy and safety of deferoxamine, deferiprone, and deferasirox on severe thalassemia: a meta-analysis of 16 randomized controlled trials. PLos One. 2013;8(12).

21. Smith C, Cooksey E, Duncan I. Myelin loss does not lead to axonal degeneration in a long-lived model of chronic demyelination. J Neurosci. 2013;33(6):271827. 